\title{
Blueprint as a Motivating Factor for the Development of Spatial Ability in Teaching of Mathematics: An Action Research Study
}

\author{
Lucia Rumanová ${ }^{1}$, Dušan Vallo ${ }^{1}$, Edita Smiešková ${ }^{2}$ \\ ${ }^{I}$ Department of Mathematics, Faculty of Natural Sciences, Constantine the Philosopher University in Nitra, \\ Tr. A. Hlinku 1, 94974 Nitra, Slovakia \\ ${ }^{2}$ Art Industrial Private School, Samova 14, 94901 Nitra, Slovakia
}

\begin{abstract}
We focused on connecting active methods and the historically known technique named blueprint in educational process of mathematics in this paper. The alternation of methods contributes to the variety and diversity of the teaching process, making the educational process more interesting and engaging for students. We prepared interesting worksheets for the students. The purpose of this study is to analyze active students' work during several math lessons. We preferred a qualitative approach to research, namely action research, considering of the self-critical analysis of partial results, typical for this research.
\end{abstract}

Keywords - geometry, education, motivation, action research, worksheets, evaluation.

\section{Introduction}

In 2018, the Intergovernmental Committee for the Protection of the Intangible Heritage of UNESCO approved the registration of the multinational nomination "Blueprint" on the Representative List of the Intangible Cultural Heritage of Humanity UNESCO, which was submitted by the Slovak

DOI: $10.18421 /$ TEM102-30

https://doi.org/10.18421/TEM102-30

Corresponding author: Lucia Rumanová,

Constantine the Philosopher University in Nitra, Tr. A .

Hlinku 1, 94974 Nitra, Slovakia.

Email: Irumanova@ukf.sk

Received: 28 January 2021.

Revised: 12 April 2021.

Accepted: 19 April 2021.

Published: 27 May 2021.

(cc) BY-NC-ND (C) 2021 Lucia Rumanová, Dušan Vallo \& Edita Smiešková; published by UIKTEN. This work is licensed under the Creative Commons AttributionNonCommercial-NoDerivs 4.0 License.

The article is published with Open Access at www.temjournal.com
Republic together with Germany, Austria, the Czech Republic and Hungary. Along with the nomination, the Committee also praised the set of measures aimed at the transmission, protection and promotion of blueprint technology, focused mainly on educational programs supporting the raising of awareness of young people, partnerships with technical and vocational schools [1].

The history of blueprinting - the technique of dyeing fabric material using blue paint from an indigo tree dates back to the 18th century in Slovakia. This traditional craft with a strong penetration into folk art, dominated by geometry and harmony, is now again enjoying considerable popularity [2].

The geometric nature of blueprint is therefore an ideal motivating element for high school students. Specifically, in the article we will focus on the development of spatial imagination and geometric thinking of high school students. We will show how the requirements for educational outcomes in the thematic unit Cube and its properties, the cube net, which defines the National Program of Education as the official document for all Slovak schools (named ISCED 3a), can be fulfilled.

Due to the specificity of the choice of topic and the sample of respondents, we prefer a qualitative approach to research, namely action research. The self-critical analysis of partial results, typical for action research, will be based on the theory of didactic situations and methods of a-priori and aposteriori analyzes.

\section{Theoretical Background}

The issue of arousing students' interest in the content of education and their proper motivation to study is a widely discussed topic in various pedagogical and scientific studies. From the point of view of teaching mathematics, such components of motivational action that encourage mathematical activity are decisive in the teacher-student- 
curriculum relationship. An activity in which a mathematics teacher influences the motivational sphere of a student's personality in various ways and creates basic preconditions for those active in the study of mathematics is presented. The aim is to bring students to study mathematics for their own interest, for the need to know the mathematical world, so that they do not regret time, nor energy for the development of their own mathematical culture [3].

Practical management of motivation is therefore extremely important for the teacher, as it allows him to understand the reasons for student activity led in a certain direction [4].

Internal mathematical motivation is important for the development of mathematics. These are stimuli transmitted from the inner mathematical world, manifested by typical ways of thinking, especially precise expression, exhaustive completeness, systematics, the search for dependencies, as well as the usefulness of new definitions and concepts [5].

However, the reflection of this typical exactness of mathematics has a negative effect in the current pedagogical process. The content of education becomes more isolated and unnecessarily complicated for students. Students need to be explained the validity of the curriculum by answering the questions of why we learn it, why we follow this method, and what is the meaning of this solution [6].

In this way, the internal mathematical motivation to study mathematics becomes the external motivation of the pupil to learn mathematics, which is conditioned by the expectations of teachers and parents to meet the requirements of the school and study plans. Constructivist approaches to teaching are limited, as students are blocked from a positive attitude towards mathematics and knowledge is often formalized [7].

At the same time, some generally accepted pedagogical principles that define motivation as an effective part of cognitive and teaching activity are disappearing. One of the basic principles of humanistic education is the motivation of students through more space for creativity and activity of students [8], [9].

It follows from the above that internal motives, such as the joy of work, creation, discovery and play, are decisive for the teaching of mathematics from the student's point of view [10]. It is important for the teacher to develop practical experience in motivating students. Action research is an effective method.

According to [11], action research is a process in which its participants study a scientific problem in order to evaluate it, improve it and move towards change in practice.

Authors in [12] write that "doing action research means planning, acting, observing, and thinking more carefully, systematically, and more accurately than people do in everyday life."

[13] mentions action research as a systematic study that combines action with the aim of improving practice. Author [14] in turn, believes that action research is a combination of action and research.

According to [15], action research could not only contribute to the practice and theory of teaching and learning through its accessibility to teachers. By its very nature, teaching makes more meaningful [16]. It is important to note that action research is an effective tool for change and improvement at the local level. The teacher resp. and a group of teachers who are working as a researcher try to improve their practice within the classroom or school in which they work [17], [18].

Action research in the field of pedagogical activity of a teacher is thus a process in which the teacher verifies his pedagogical activity through strategies, methods and tools of pedagogical research. Action research helps him to better identify the problems of his own practice, solve them and then evaluate the application of the proposed solutions in teaching [19]. According to [20] the methodological specifics of action research, research is cyclically repetitive, participatory, qualitative and reflecting on partial results. As it is a repetitive cyclic process, it has its phases.

Author [21] describes action research with repeated four steps (as shown in Figure 1 below):

- strategic planning;

- acting (action, activity), implementation of the plan;

- observing, evaluation and self-evaluation;

- reflecting, critical and self-critical reflection of the obtained results and subsequent decision for the next cycle of action research.

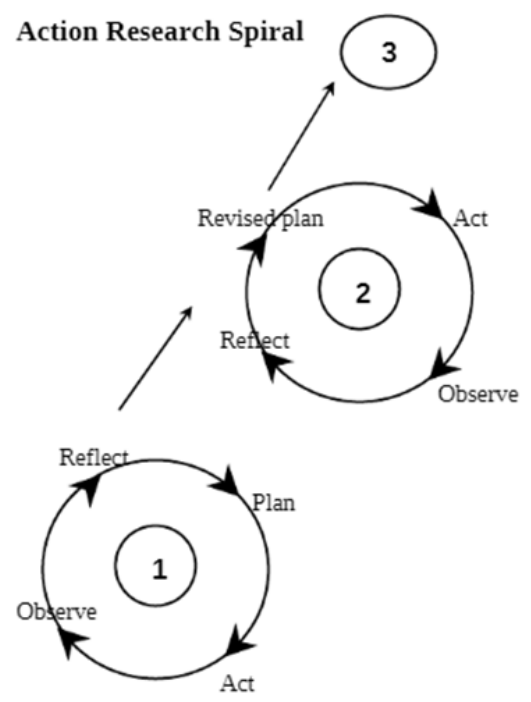

Figure 1. The spiral of action research cycle (Source: [21]) 
It follows from the above that the purpose of action research in educational practice is to immediately improve or otherwise positively influence any component of teaching or a selected thematic unit. Objectively, an action research is usually short-term and conducted on a small sample of students. The obtained results are applicable only to the examined sample of respondents, as they respond to detailed problems of practice.

The article [22] states that geometry is also a critical point of mathematical education in our schools. The school curriculum in geometry is a reflection of ideas about axiomatic construction, which is a mistake. From the beginning, the teaching of geometry should be oriented towards the knowledge of the space in which the student lives, and the teaching should systematically develop the imagination. Spatial ability is one of the important abilities of a person. Spatial ability develops throughout the life of an individual, but especially through purposeful, controlled teaching of mathematics at school [23].

Taking into account the educational process, spatial ability is one of the key competences of the pupil, especially in relation to teaching geometry. There are three basic factors of spatial ability spatial relations (mental rotation with figures), spatial orientation (ability about imagining figures in different position) and spatial visualization (based on solution of tasks) [24], [25]. Spatial ability is defined by these psychological foundations and it is divided into three levels - intuitive visualization, geometric visualization and spatial thinking [26].

As mentioned above, an important phase of action research is the critical reflection of the results obtained and the subsequent decision for the next cycle of action research. Various data analysis methods can be used for this. One of the important methods is a-priori analysis and a-posteriori analysis, which we used to test the tasks we created and were created within the Theory of Didactic Situations (TDS). They are based on the arrangement of individual levels of the environment and situations, between which there is mutual interaction and create the so-called levels of didactic situations. Research base of the theory of didactic situation (TDS) issued from this didactic school is analysis of problem in particular levels of didactic situations [27], [28], [29].

The theory of didactic situations in mathematics is based on the assumption that for mathematical knowledge it is possible to model at least one corresponding mathematical situation. It therefore studies the logical, mathematical and ergonomic elements that are needed to create such situations [30].
At present, the methods of a-a priori and aposteriori analyzes are used mainly as a tool for teachers in creating lesson preparation [10]. Theory of didactic situations provides a systemic framework for investigating teaching and learning processes in mathematics. The theory is structured around the notions of a-didactical and didactical situations (apriori analysis, a-posteriori analysis ...) which are relevant for teaching and learning in mathematics [31].

According to [32], a-priori analysis should help the teacher to plan the lesson and select educational activities. He emphasizes that the basis is the subsequent comparison of the a-priori analysis with the a-posteriori analysis, which will allow e.g. interpret students' unexpected strategies and arguments, reveal mistakes they have made, etc.

Authors [33] argue that the a-priori analysis is less tied to the specific situation and relationships in the classroom than the a-posteriori analysis. Thanks to aa priori analysis, teachers are able to discuss more general issues of teaching mathematics and learning mathematics. They consider it important that research as well as practice in mathematics education use both types of analysis, a-posterior analysis and apriori analysis.

In the-a priori analysis of our research, we identified didactic variables that represented possible solutions for students. We interpreted the results of the strategies used in the students' procedures using C.H.I.C. (Implicative and Cohesive Hierarchical Classification). Statistical Program C.H.I.C. offered us a comparison of the similarity of didactic variables determined in a thorough a-a priori analysis, points to the relationships of cohesion between the variables and the percentage of probability of their implementation also expresses the probability of implications between the variables. The software also monitors the relationships between several categories and other variables, providing a link between quantitative and qualitative a-posteriori analysis.

\section{Blueprint as Motivating Factor}

The mathematical nature of blueprint is based on the theory of wallpaper symmetry groups. It is not about covering the plane without gaps, but about ornaments - shapes that are pressed onto the canvas in two mutually perpendicular directions by means of special molds (see in Figure 2).
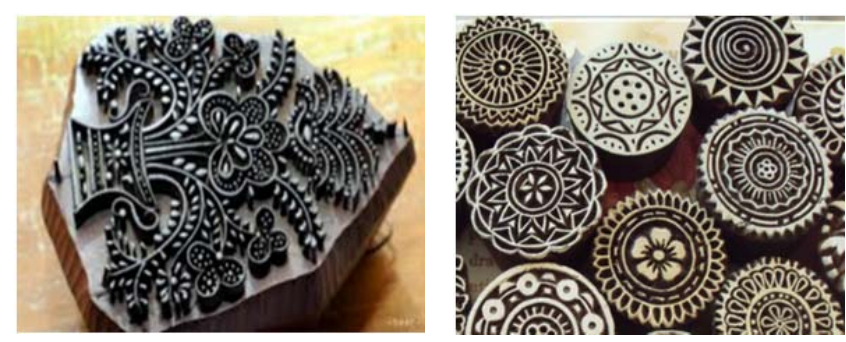

Figure 2. Molds for blueprint. (Source: [34]) 
The composition of the ornament is not simple (Figure 3), it is mostly a folk art motif, in which the abstraction and creativity of its creator is manifested [35].

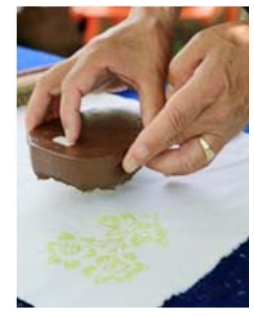

a)
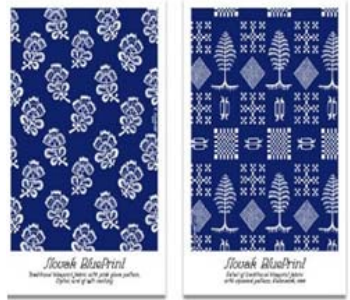

b)

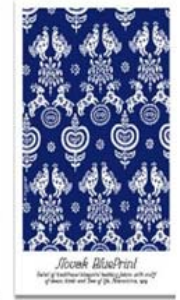

$y=-m$
Figure 3. Molds for blueprint. Blueprint in work samples: (a) Blueprint from the workshop (Source: [36]); (b) Example of traditional Slovak blueprint (Source: [34])

\subsection{Action Research (Phase 1): Strategic Planning}

The ISCED 3A state education program is a binding document that sets out the general objectives of education and the key competencies to which education should be directed at secondary schools in Slovakia. Within this program, the educational area of Mathematics and Work with Information is defined. This area is defined by the thematic area of Geometry and Measurement, where students explore and discover planar and spatial shapes, solve positional and metric problems from ordinary reality, and the development of spatial imagination has an important place [37].

The key - starting body, on which the spatial imagination of students develops as a priority, is the cube. Various computational tasks on the surface and volume of the cube, planar sections of bodies are associated with tasks directly supporting the development of spatial imagination. These are problems of visualization of cube structures and problems about cube nets [38], [39].

The teaching of mathematics at secondary art schools has to be governed by the requirements of generally valid documents. However, it should be noted that three art departments teach art, graphic design and photographic design at secondary art schools. Schools always accept new students on the basis of a talent test, which consists of a still life drawing, the creation of a spatial object and the evaluation of homework.

Emphasis in teaching is placed on practical subjects with an artistic focus, academic subjects such as mathematics or other natural sciences are taught with a lower hourly allowance in accordance with state content and performance standards for this type of school [37].
Specifically, the subject of mathematics is taught in each year, but with a time allowance of 1 teaching hour per week.

We conducted the research on a sample of 23 students in 1 grade of the second year (19 girls, 3 boys). From the beginning of the school year, mathematics was taught for the first three months according to the prescribed textbooks for secondary vocational schools. The overall average of the marks from the math certificate was 2.24. There was no student in the class who was fully respected by all students. The class did not have a leader, despite the fact that there were several leaders in the class. Seven students usually did not work in the class, 8 other students were always actively involved in teaching. The remaining students participated in the teaching process sporadically, according to the topic. Overall, we identified a low interest of students in the subject in this class, which sometimes turned into a negative attitude towards any activity in the class.

In the form of an interview with students, we gradually identified the following causes:

- Students perceived the presented secondary school curriculum as demanding and unmanageable. The mathematics curriculum followed on from the knowledge and skills from primary school, which the students lacked, e.g. insufficiently mastered multiplication and division of decimal numbers, counting with fractions, ignorance of mathematical symbols and difficulties in understanding a mathematical text (low literacy).

- The mathematical curriculum focused on numerical calculations and modifications of algebraic expressions was considered uninteresting in its content, time consuming and completely unnecessary in the "time of calculators".

- Students did not perceive the mathematics curriculum as necessary for their further profession and professional development. Exceptions, they were geometry, especially structural geometry, spatial imagination tasks, historical tasks, logical puzzles, and "stories to which a story relates."

The findings from the interviews raised the question of whether the interest of high school students in mathematics can be perceived as a longstanding problem.

Through an online questionnaire, we contacted former graduates of several secondary art schools in Slovakia and asked them for their opinions. We were interested in the answers of the respondents to the questions: 
- No. 1: How was the teaching of mathematics at a secondary art school?

- No. 2: What is your opinion on teaching mathematics at a secondary art school?

- No. 3: Which thematic units of mathematics do you think are unnecessary for high school students?

- No. 4: What thematic units do you think were missing from the curriculum?

- No. 5: How do you think the effectiveness of teaching mathematics in secondary art school could be increased?

The questionnaire was filled in by 14 respondents aged 23 - 26 years, of which 9 were currently studying at universities (only three of them at the art department at universities). We select a few examples from their answers. In parentheses are the changed names of the respondents and their age.

Answers to question No. 1: "We only had math in the first two years of high school, we had books, but we rarely used them. Aids: a blackboard." (Daniela, 25); "The teacher entered examples on the board. The class counted. We didn't get much further in the material than the curriculum in elementary school. We didn't use the textbooks at all, and I don't think we had any." (Gabriele, 25); "The teacher worked classically as in every school, only we were not as demanding as in other schools" (Ivana, 25).

Answers to question No. 2: "My view is that there could be more mathematics for artists." (Alena, 25); "I don't think math is completely useless, certainly some subjects are important, but no one enjoys mathematics at this type of school. It is certainly not the goal of interest of students who have decided to study at Art Industrial School Private." (Eva, 23); "Mathematics is needed, but the curriculum could be more adapted to the needs of art students." (Gabriele, 25); "Mathematics is an absolutely useless subject; it has not given me anything" (Frederica, 25).

Answers to question No. 3: "In my view, these are entities such as statistics, probability, and combinatory" (Beáta, 24); "Everything" (Frederica, 25).

Answers to question No. 4: "Perhaps it would be appropriate to focus on the mathematical solution of the composition" (Jana, 25); "More geometry" (Caroline, 26).

Answers to question No. 5: "New teaching methods, demonstrations, more tasks." (Daniela, 25);

"Certainly, teaching methods should be changed (a more playful form to attract, not stereotypical teaching), applied more to practice (it could be very nicely combined with art)." (Eva, 23); "I think it would be beneficial to include some practical tasks, uses in teaching mathematics in art practice." (Jana, $25)$; "It could be more linked to the practice being developed in order to be able to calculate the proportions, etc.," (Caroline, 26).

The overall analysis of the answers of former graduates revealed the following facts:

- The use of textbooks in the teaching of mathematics in art schools is rare;

- Students and graduates felt that the teacher had high demands on them; however, they do not criticize the work of the teacher;

- The interest of art school students in teaching mathematics was low, students focused more on the study of art and art-oriented subjects, they did not perceive mathematics as a subject necessary for their future career;

- Graduates criticized the curriculum (content and performance standards), which they proposed to adapt to the needs of students in this type of school. They considered as thematic units such as combinatory, statistics, probability;

- They lacked more practically oriented curriculum in geometry in teaching, e.g. the mathematical solution of the composition, the content part of planimetry and stereometry focused purely theoretically were rejected as unnecessary;

- In their opinion, new ones could contribute to a more effective teaching of mathematics teaching methods, textbooks, material aids and tasks with a link to art practice.

Based on the above, we define the objectives as follows:

1. activate students in teaching mathematics;

2. motivate students to learn mathematics;

3. create a space for students to think creatively and discover in the teaching of mathematics;

4. And also we define four research questions thus:

5. How to activate high school students to study mathematics?

6. Is it possible to motivate students to study selected thematic units in geometry using interesting tasks?

7. How to link the teaching of mathematics with the fine arts?

8. Does active manipulative activity with material aids affect the performance and durability of the student's knowledge?

\subsection{Action Research (Phase 2): Action, implementation of the plan}

In an effort to comply with the requirements defined in [37], we decided to "revive" the stereometrical curriculum on cube nets as follows. We created a plan that was based on creating tasks combining fine arts and mathematics. The context of the tasks was to be based on the fine arts in order to activate the students and motivate them to act. 
The principle of blueprinting is based on pressing various stamps and patterns on the canvas, which is mostly rectangular in shape. In order to motivate them to work, we showed students specific examples of blueprints on textiles and various useful objects and then we explained the history of blueprints, its impact on folk culture and traditions, the very technique of this craft.

We planned activities that were preceded by a short repetition of the curriculum on identical representations (axial symmetry, central symmetry, displacement and rotation) from the previous year.

We have prepared material aids such as drawings, paper models of various nets of cubes, stamps, scissors and drawing aids. In the following, we used various paper templates of a net of cubes as a starting material - a "canvas" for printing.

We have created several worksheets marked A, B, $\mathrm{C}, \mathrm{D} 1, \mathrm{D} 2, \mathrm{D} 3$ and $\mathrm{E}$ respectively (examples of worksheets A, B, C are in the Appendix A).

The worksheet A focused on students' ability to know and correctly identify cube nets. In the second worksheet (worksheet B), students had to draw other nets of cubes, of course, in addition to the nets listed in worksheet A. In worksheet C, students had to identify all possible cube nets.

Worksheets could be used in one lesson. In the next lesson, in order to differentiate the work of students, one of the variants of worksheets D was used. The essence of worksheets D1, D2, D3 (see Appendix B) was the development of spatial ability with the following problem assignment: "Place the stamps on the cube net so that, when the net is folded and placed on the marked face, they form an aesthetically arranged blueprint pattern."

The last worksheet E (can see in Appendix C) was developed as a homework exercise. Students had to repaint the blueprint pattern from the cube net to another cube net so that they would look identical when the net was folded.

\subsection{Action Research (Phase 3): Observation, Evaluation and Self-Evaluation}

In the analysis of student solutions, we used the method of a-priori and a posteriori analysis. In the -a priori analysis, based on the knowledge of students' knowledge level, we assumed that it was necessary to devote more teaching hours to solving individual worksheets.

At the same time, we decided that a preparatory phase was needed, so we devoted one lesson to training the spatial imagination of students, where students solved tasks on constructions from cubes (elementary school curriculum, example is in Figure 4). In the 2 nd lesson we repeated the concept of a cube nets and only in the 3rd lesson we decided to give students tasks from the prepared worksheets.

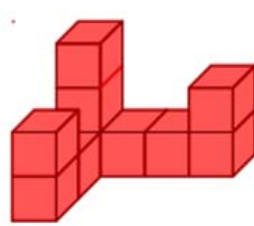

a)

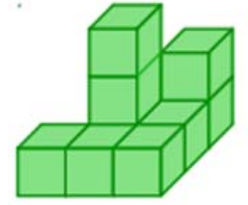

b)

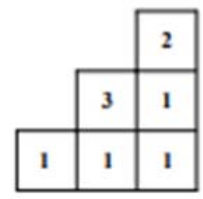

c)
Figure 4. Demonstrations of cube structures: (a) Example of cube structures; (b) Cube structures with top view and number of cubes in the column

The reason for this was simple. We assumed that students did not know the dice nets and would most likely not be successful in solving worksheets. A possible failure could have a demotivating effect.

As part of the-a priori analysis, we dealt with possible solutions to the submitted tasks from students. We considered the following to be the correct solutions for the individual worksheets:

- worksheet A - the right solution if students have marked all three nets of the cube correctly;

- worksheet B - we only accepted the number of new dice nets, we did not count nets that were mirrored or rotated, students could draw a maximum of 9 additional nets of cubes;

- worksheet $\mathrm{C}$ - the purpose of the worksheet was to show students all the possible nets of dice, we did not evaluate this worksheet;

- worksheets D1, D2, D3 - the difference of worksheets was to ensure independent work of students, we accepted as the right solution if the student correctly placed all the stamps on all the dice nets;

- worksheet E - the correct solution for the worksheet was if the students correctly redrawn the pattern on all the cubes.

We found that (see Figure 5):

1. Worksheet A was correctly solved by 16 students.

2. In Worksheet B, half of the students drew four new nets of cubes, more than four were drawn by three students, and less than four nets of cubes were drawn by seven students. From the graphs obtained using C.H.I.C., we divided the student solutions into two groups: a group of students who drew 4 or more nets of cubes and a group of students who drew less than 4 nets of cubes.

3. Worksheet D1, D2, D3 - Worksheet D1 was solved by seven students and five correctly, D2 was solved by six students and four of them correctly, D3 was solved by seven students and six of them correctly. A total of 15 students were able to solve the task correctly.

4. Worksheet E was handled correctly by 15 students and redrawn by a blueprint. In Figure 5 there is the correct solution of worksheet D3, and the correct solution of worksheet E. 

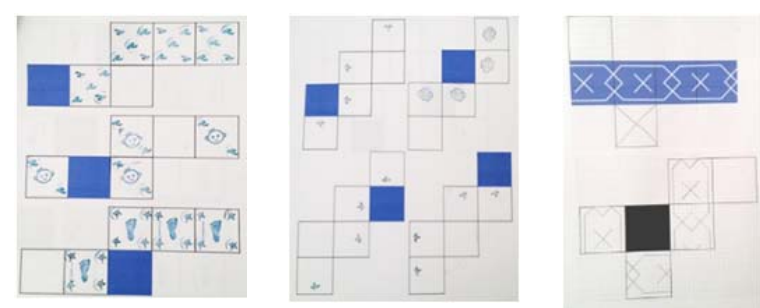

Figure 5. Student solutions of tasks from worksheets

Worksheet D solutions could be divided into four categories:

- Category 1: Students who understood the task assignment and solved the task correctly, five students (Figure 6).
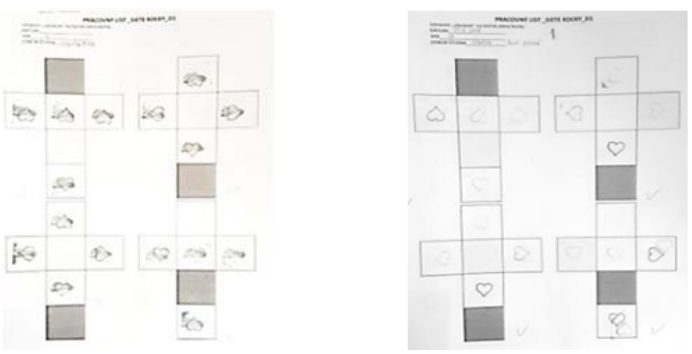

Figure 6. Correct solutions of students (Category 1)

- Category 2: Students who understood the task assignment but could not imagine the solution, one pupil.

- Category 3: Students who did not fully understand the task were placed on the sides of the cube, but the orientation of the stamps after assembling the cube was not correct, three students. We can see example in Figure 7.
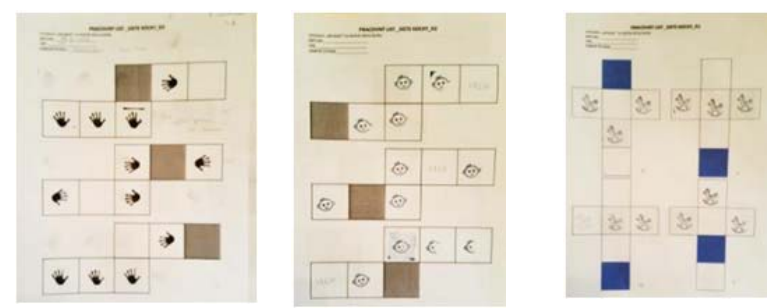

Figure 7. Solution of students (Category 3)

- Category 4: Students who did not understand the task and placed the stamp at random, two students (one example can be seen in Figure 8).

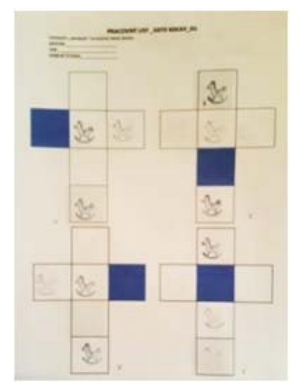

Figure 8. Students' solutions (Category 4)
Students were given a worksheet E for homework. Seven students brought a correctly solved homework assignment. The teacher used formative assessment of students during the learning process.

\subsection{Action Research (Phase 4): Critical and Self-Critical Reflection of the Obtained Results}

We interpreted the results of the students' solutions using C.H.I.C. Didactic variables were based on the student's correct resp. incorrect solution of the task. The variables we used were four A, B, D, and E (according to the designation of the worksheets); we did not evaluate worksheet $\mathrm{C}$. We marked the correct solution of the student in the given worksheet 1 and incorrectly 0 . We graphically displayed the relationship between the individual variables similarity tree, implicative tree and implicative graph.

The aim was to find out whether there is a relationship between solving the first worksheets (i.e. whether it is important for students to have a good knowledge of cube nets, and solving worksheets D and E). From the similarity tree (Figure 9) we see a relationship with $96 \%$ cohesion.

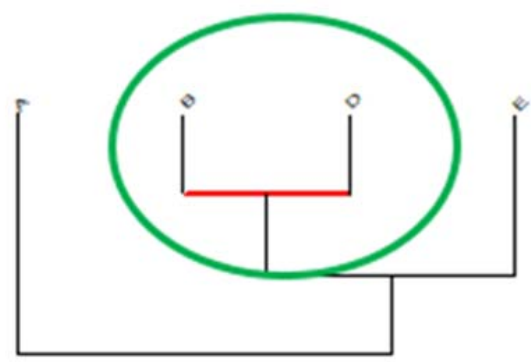

Figure 9. Similarity tree

The implicative tree (Figure 10) confirms this fact. This relationship means that students who were able to draw four or more cubes of a cube were able to solve problems from Worksheet D. In contrast, students who drew less than four nets of cubes had difficulty solving problems from Worksheet D.

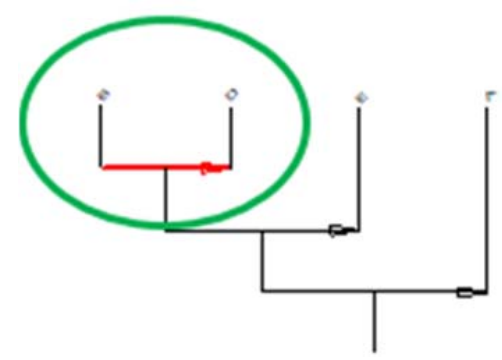

Figure 10. Implicative tree

We see the same results on the implicative graph (Figure 11). In addition, the implicative graph also shows the relationship between variables $\mathrm{B}, \mathrm{A}$ and $\mathrm{E}$, 
D. If students were able to draw more than four nets of cubes, they were probably successful in solving worksheet A. Students who correctly solved worksheet $\mathrm{E}$ were also likely to solve correctly worksheet D.

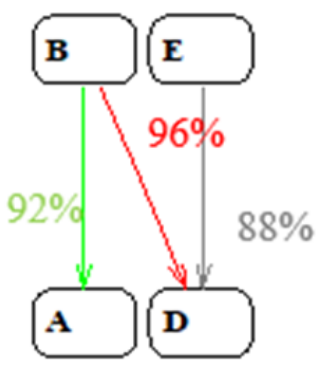

Figure 11. Implicative graph

Finally, as part of the evaluation of worksheets, we asked students for their opinion on the assignments and formal processing of worksheets. According to the students, the worksheets were:

- really interesting and motivating for students;

- creatively and it is a way to arouse students' interest;

- combine mathematics and fine arts;

- help students to better understand cube nets and develop students' spatial imagination.

\section{Discussion}

The role of the teacher is to motivate students to learn in order to gain expertise. At the same time, his activity should also develop the personality of his students by stimulating the desire for creative activity and usefulness for society, interest in knowledge, as well as the effort to obtain a good evaluation.

Mathematics competencies derived from the PISA framework [40] are discussed in many studies in mathematics education (can see in [41], [42]). The National Curriculum for Upper Secondary Education [37] is the document, which specifies stereometry as one of the major topic. A majority of mathematics teachers states that the teaching of the stereometrical curriculum is difficult thematic unit. The many teachers and experts in didactic of mathematics concur to in the conviction that a high level of spatial imagination is necessary to solve stereometrical tasks. On the other side the problem with motivation to study the geometric curriculum is also relevant. Each geometric problem is unique and there is basically no single algorithm for solving geometric problems. Therefore, solving geometric problems requires a special approach, creative thinking and a combination approach. If a student is to succeed in solving a problem, he has to accept the mathematical problem as a personal problem that he wants to solve.
We believe that this is a way to motivate students. We chose a highly specific blueprint theme as an overlap between the required math curriculum and the future professional careers of our students. The blueprint context can open the new window how to active and motivating mathematics lessons in natural studying patterns, shapes and geometrical ornaments.

It offers the fulfilment of the needs of students who perceived mathematics only as a compulsory subject without affecting their future professional orientation.

The tasks we included in the teaching process were very simple for some students, but difficult for other students. We have come to the conclusion that it is not expedient to give students new geometric problems, the solutions of which require the application of previous knowledge of mathematics. However, if necessary, it is desirable to repeat the mathematical knowledge with the students before a specific lesson.

We verified this fact on the relationships among the solutions of the individual worksheets. In order for students to be able to correctly solve problems in which it is desired to use the idea of blueprint to cover the nets of the cube under pre-specified conditions, it is necessary to master the basic knowledge of the geometry of this spatial solid.

It is obvious that solving this type of problems has improved students' knowledge of mathematics, art and history. Students also acquired better skills in working with drawing aids, which are essential for further study of their field.

We managed to motivate students to work and cooperate in education process, and thus learn mathematics. We also observed some changes in students' behavior and attitudes. Students cooperated more in mathematics lessons, gained more practice and positive experiences with geometric subjects, they communicated better with each other, and the working climate in the class was also improved.

In conclusion, we also note that the fulfilment of content standards is an important indicator of results of teacher's work. Many factors affect the results. We consider motivation to be the most important fact, which we have demonstrated through our action research. We also came to the conclusion that it is appropriate to combine several forms and methods of work during the teaching process, especially for those that are tied to the manipulation of real objects and activities. The alternation of methods contributes to the variety and diversity of the teaching process, making the educational process more interesting and engaging for students. Although action research is aimed at smaller groups, we believe that these facts can be applied in general. 


\section{Acknowledgements}

This work was partially supported by the Ministry of Education, Science, Research and Sport of the Slovak republic, name of the project "Inspirational Didactic Processes in Teaching of Projection Methods in Secondary Mathematics Education with a Focus on Requirements of Society and Practice”, project number $019 U K F-4 / 2020$.

\section{References}

[1]. Danglová, O. (2014). Modrotlač na Slovensku/Blueprint in Slovakia. Ústredie l'udovej.

[2]. Krišková, Z. (2018). Kultúrne Dedičstvo A Jeho Potenciál V Kontexte Udržatel'ného Rozvoja: Modrotlač Ako Kultúrnoidentifikačný Prvok Na Reprezentatívnom Zozname Nehmotného Kultúrneho Dedičstva. Muzeológia a kultúrne dedičstvo, 6(2), 95-106.

[3]. Jedinák, D. (2018). Smerom k motivácii štúdia matematiky. Pedagogická orientace, 3(8-9), 59-69.

[4]. Dargová, J. (2001). Tvorivé kompetencie učitel'a. Privatpress.

[5]. Schwarz, Š. (1986). Prečo a ako zvyšovat' matematickú kultúru. Pokroky matematiky, fyziky a astronomie, 31(6), 314-326.

[6]. Hejný, M., Bálint, L., Benešová, M., Bereková, H., Bero, P., l'udmila Frantíková, ... \& Vantuch, J. (1989). Teória vyučovania matematiky. SPN.

[7]. Molnár, J., Schubertová, S., \& Vaněk, V. (2008). Konstruktivismus ve vyučování matematice. Univerzita Palackého v Olomouci.

[8]. Lokšová, I., Lokša, J., \& Koubská, P. (1999). Pozornost, motivace, relaxace a tvořivost dètí ve škole: teoretická východiska a praktické postupy, hry a cvičení. Portál.

[9]. Turek, I. (2014). Didaktika. Praha: Wolters Kluwer CZ, a.s.

[10]. Hejný, M., \& Novotná, J. (2004). Dvacet pět kapitol $z$ didaktiky matematiky. Praha: Pedagogická fakulta UK.

[11]. Corey, S. M. (1953). Action research to improve school practices. New York: Bureau of Publications, Teachers College, Columbia University.

[12]. Kemmis, S., \& Mctaggart, R. (1992). Cómo planificar la investigación: Acción. Editorial Laertes,.

[13]. Ebbutt, D. (1985). Educational action research: some general concerns and specific quibbles. Issues in educational research: Qualitative methods, 7(2), 152-174.

[14]. Hopkins, K. (1985). Death and Renewal: Volume 2: Sociological Studies in Roman History (Vol. 2). Cambridge University Press.

[15]. Stenhouse, L. (1979). Case study in comparative education: Particularity and generalisation. Comparative Education, 15(1), 5-10.

[16]. Nelson, P. A., \& Elliott, S. J. (1991). Active control of sound. Academic press.

[17]. Cohen, L., Manion, L., \& Morrison, K. (2017). Research methods in education. Routledge.
[18]. Holly, P., \& Whitehead, D. (Eds.). (1984). Actionresearch in Schools: Getting it Into Perspective. Cambridge Institute of Education.

[19]. Rychnavská, M., \& Nogová, M. (2013). Akčný výzkum ako cesta skvalitňovania pedagogickej praxe učitel'ov (modelová situácia). $5^{\text {th }}$ International Scientific Conference of Lifelong Learning, ICOLLE (17. - 18. 9. 2013), Brno: Mendel University, 5, 385394.

[20]. Hendl, J. (2005). Kvalitativní výzkum: základní metody a aplikace. Portál, sro.

[21]. Zuber-Skerritt, O. (2001). Action learning and action research: paradigm, praxis and programs. Effective change management through action research and action learning: Concepts, perspectives, processes and applications, 1, 20.

[22]. Kuřina, F. (2015). Kritické jevy naší školské matematiky. Matematika-fyzika-informatika, 24(4), 241-251.

[23]. Perný, J. (2003). Rozvíjení prostorové představivosti a tvorivost. Proceedings of the International Conference the Decidable and the Undecidable in Mathematics Education, Brno, Czech Republic, 1218.

[24]. Lohman, D. F. (1979). Spatial ability: A review and reanalysis of the correlational literature. Stanford University Technical Report No. 8, CA.

[25]. Lohman, D. F. (1988). Spatial abilities as traits, processes, and knowledge. In R. J. Sternberg (Ed.),Advances in the psychology of human intelligence (pp. 181-232). Hillsdale, NJ: Erlbaum.

[26]. Šedivý, O. Výučba geometrie, priestorová predstavivost' a humanizácia vyučovania geometrie. Acta Mathematica 1 (1), Nitra, Slovak Republic, 19 27.

[27]. Brousseau, G. (2006). Theory of didactical situations in mathematics: Didactique des mathématiques, 1970-1990 (Vol. 19). Springer Science \& Business Media.

[28]. Chevallard, Y. (1992). Concepts fondamentaux de la didactique: perspectives apportees par une approche anthropologique. Recherches en Didactique des Mathematiques, 12(1), 73-112.

[29]. Sierpinska, A. (2003). Lecture Notes on the Theory of Didactic Situations in Mathematics. Concordia University.

[30]. Nováková, H. (2013). Analýza a priori jako součást přípravy učitele na výuku. Scientia in educatione, 4(2), 20-51

[31]. Artigue, M., Haspekian, M., \& Corblin-Lenfant, A. (2014). Introduction to the theory of didactical situations (TDS). In Networking of theories as a research practice in mathematics education (pp. 4765). Springer, Cham.

[32]. Charnay, R. (2003). L'analyse a priori, un outil pour l'enseignant. Actes des journées d'étude sur le Rally mathématique transalpin, RMT: potentialités pour la classe et la formation, 3, 199-213.

[33]. Sollervall, H., \& Stadler, E. (2015). Validating affordances as an instrument for design and a priori analysis of didactical situations in mathematics. International Journal for Mathematics Teaching and Learning. 
[34]. ÚL'UV. (2020). Courtesy of ÚL'UV - the Centre for Folk Art Production. Retrieved from: http://www.uluv.sk/en/web/home. [accessed: 15 January 2021].

[35]. Čeretková, S., Smiešková, E. \& Naštická, Z. (2014) Geometry in Slovak Blueprint. Scientia Iuvenis, Constantine the Philosopher University in Nitra: Nitra, Slovakia, 1, 363-369.

[36]. Trnka, P. (2020). Modrotlač Trnka. Retrieved from: https://www.modrotlac.sk. [accessed: 15 January 2021].

[37]. Štátny pedagogický ústav. (2017) Inovovaný štátny vzdelávací program. Retrieved from: https://www.statpedu.sk/files/articles/dokumenty/ino vovany-statny-vzdelavaciprogram/matematika g 4 r.pdf. [accessed: 20 January 2021].
[38]. Vidermanová, K. I. T. T. I. (2008). Využitie stavebnice Polydron vo vyučovaní stereometrie. Didaktické hry a aplikačné úlohy vo výučbe matematiky pre, 2, 39-42.

[39]. Vidermanová, K., Viziová, A., \& Záhorská, J. (2012). Analýza žiackych chýb pri konštrukcii rezov telies a možnosti ich odstránenia využitím programu Cabri 3D. Acta Mathematica 15, 179.

[40]. De Lange, J. (2006). Mathematical literacy for living from OECD-PIA perspective. Tsukuba Journal of Educational Study in Mathematics, 25, 13-35

[41]. Van der Kooij, H. (2010). Mathematics at work. Proceedings of the International Group for the Psychology of Mathematics Education, 1, 121-124.

[42]. Chrysostomou, M., \& Mousoulides, N. (2010). Teachers'beliefs About The Adoption Of New Technologies In The Mathematics Curriculum. of the European Society for Research in Mathematics Education, 1270. 
TEM Journal. Volume 10, Issue 2, Pages 732-742, ISSN 2217-8309, DOI: 10.18421/TEM102-30, May 2021.

\section{Appendix}
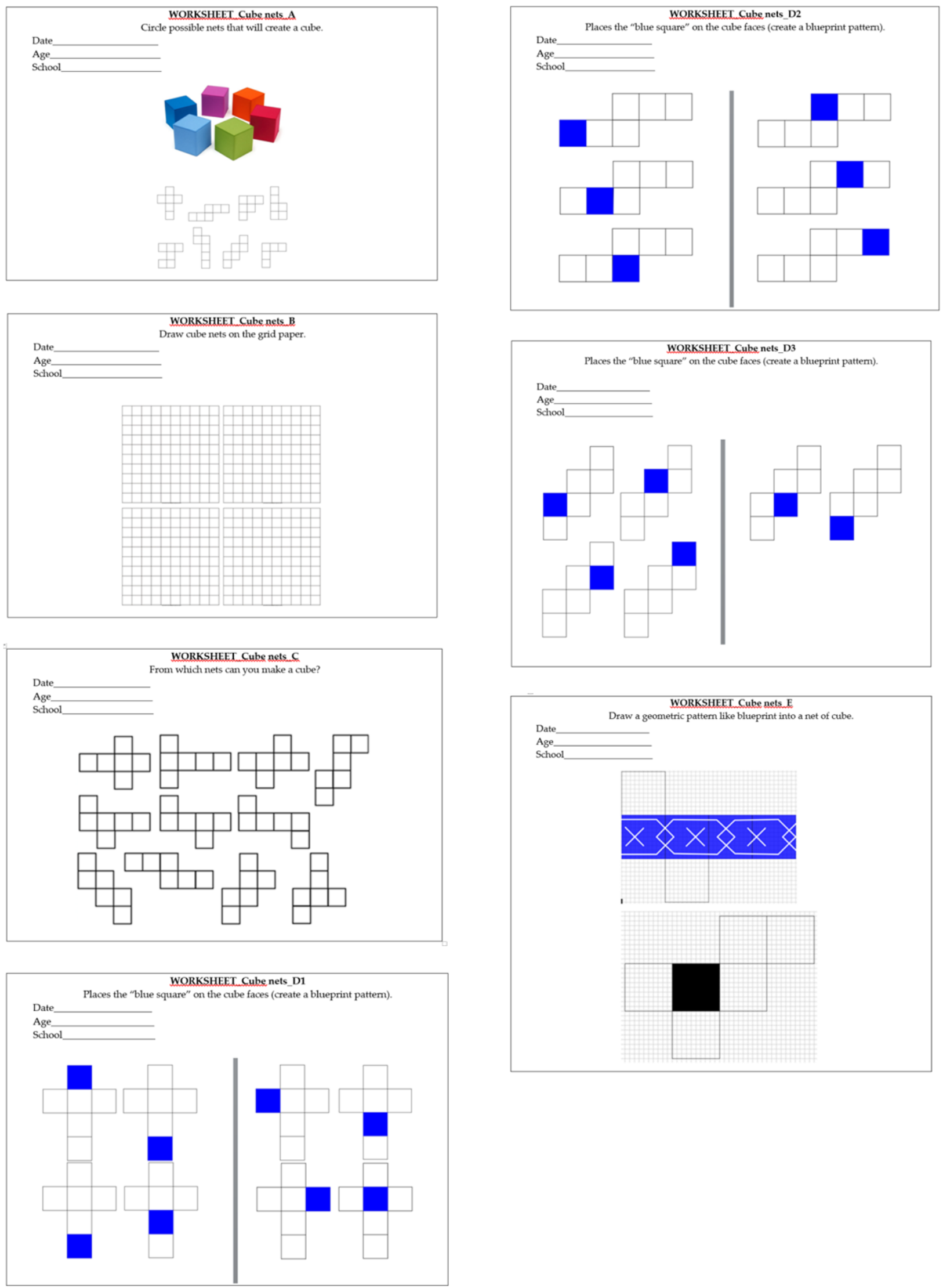